\title{
CLIC4 Gene
}

National Cancer Institute

\section{Source}

National Cancer Institute. CLIC4 Gene. NCI Thesaurus. Code C21179.

This gene plays a role in the regulation of several cellular processes, including cellular transport. 